\title{
Potential of bacteriophages as disinfectants to control of Staphylococcus aureus biofilms
}

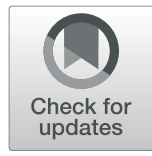

\author{
Jun Song ${ }^{\dagger}$, Hongri Ruan ${ }^{\dagger}$, Li Chen, Yuqi Jin, Jiasan Zheng, Rui Wu ${ }^{*}$ and Dongbo Sun ${ }^{*}$
}

\begin{abstract}
Background: Staphylococcus aureus is the causative agent of chronic mastitis, and can form a biofilm that is difficult to completely remove once formed. Disinfectants are effective against $S$. aureus, but their activity is easily affected by environmental factors and they are corrosive to equipment and chemically toxic to livestock and humans. Therefore, we investigated the potential utility of a bacteriophage as a narrow-spectrum disinfectant against biofilms formed by $S$. aureus. In this study, we isolated and characterized bacteriophage VB_SauM_SDQ (abbreviated to SDQ) to determine its efficacy in removing S. aureus biofilms.

Results: SDQ belongs to the family Myoviridae and consists of a hexagonal head, long neck, and short tail. This phage can sterilize a $10^{9} \mathrm{CFU} / \mathrm{mL}$ culture of $\mathrm{S}$. aureus in $12 \mathrm{~h}$ and multiply itself 1000-fold in that time. Biofilms formed on polystyrene, milk, and mammary-gland tissue were significantly reduced after SDQ treatment. Fluorescence microscopy and scanning electron microscopy showed that SDQ destroyed the biofilm structure. Moreover, the titer of SDQ remained relatively high after the lysis of the bacteria and the removal of the biofilm, exerting a continuous bacteriostatic effect. SDQ also retained its full activity under conditions that mimic common environments, i.e., in the presence of nonionic detergents, tap water, or organic materials. A nonionic detergent (Triton X-100) enhanced the removal of biofilm by SDQ.

Conclusions: Our results suggest that SDQ, a specific lytic S. aureus phage, can be used to control biofilm infections. SDQ maintains its full activity in the presence of nonionic detergents, tap water, metal chelators, and organic materials, and can be used in combination with detergents. We propose this phage as a narrow-spectrum disinfectant against $S$. aureus, to augment or supplement the use of broad-spectrum disinfectants in the prevention and control of the mastitis and dairy industry contamination caused by S. aureus.
\end{abstract}

Keywords: Bacteriophage, Staphylococcus aureus, Biofilm, Disinfectant

\section{Background}

Mastitis, a persistent inflammatory reaction in the udder tissue of dairy cattle, is one of the most important diseases throughout the world [1]. Mastitis not only affects the health of milk-producing animals, with severe financial losses for dairy farmers, but also affects animal welfare [2]. Bovine intramammary infections can be caused by a wide variety of bacteria, fungi, and mycoplasmas $[3$,

\footnotetext{
*Correspondence: fuhewu@126.com; dongbosun@126.com

†Jun Song and Hongri Ruan contributed equally to this work.

Heilongjiang Provincial Key Laboratory of Prevention and Control of Bovine Diseases, College of Animal Science and Veterinary Medicine, Heilongjiang Bayi Agricultural University, No. 5 Xinfeng Road, Daqing 163319, P. R. China
}

4]. Staphylococcus aureus is one of the major pathogens causing bovine mastitis, and seriously affects the health and milk quality of dairy cows [5]. Biofilms play an important role in the spread of $S$. aureus and the persistence of infections [6,7]. A biofilm is a reticulated polymeric matrix produced by bacteria that can wrap the bacterial cells, and greatly enhances the bacterium's resistance to the external environment. Several studies have shown that biofilm bacteria are up to 1000-times more resistant to antibiotics than planktonic bacteria [8]. Therefore, it is necessary to prevent and control both $S$. aureus colonization and biofilm formation.

(c) The Author(s). 2021 Open Access This article is licensed under a Creative Commons Attribution 4.0 International License, which permits use, sharing, adaptation, distribution and reproduction in any medium or format, as long as you give appropriate credit to the original author(s) and the source, provide a link to the Creative Commons licence, and indicate if changes were made. The images or other third party material in this article are included in the article's Creative Commons licence, unless indicated otherwise in a credit line to the material. If material is not included in the article's Creative Commons licence and your intended use is not permitted by statutory regulation or exceeds the permitted use, you will need to obtain permission directly from the copyright holder. To view a copy of this licence, visit http://creativecommons.org/licenses/by/4.0/ The Creative Commons Public Domain Dedication waiver (http://creativecommons.org/publicdomain/zero/1.0/) applies to the data made available in this article, unless otherwise stated in a credit line to the data. 
Bovine mastitis prevention strategies, including good infection control and hygiene practices, vaccination, the culling of infected cows, and the cleaning of equipment, reduce the risk of bacterial infection and transmission [9]. It is extremely important to disinfect and sanitize dairy farms. In general, the commonly used broadspectrum disinfectants belong to chemical categories that have been shown to be flammable, light sensitive, corrosive to metals, irritating, carcinogenic, and/or toxic to livestock and humans $[10,11]$. Importantly, several studies have shown that chemical disinfectants can select for mutant bacteria, increasing the risk of the emergence of resistant strains $[12,13]$. Tap water, organic materials, or detergents can also reduce the efficacy of chemical disinfectants. Therefore, a new disinfectant is required that can be used in combination with detergents with no diminution of its effectiveness.

Since their discovery in 1915, bacteriophages have been used extensively in human and veterinary medicine, the food industry, and various agricultural settings. They are mainly used to control common bacterial contaminants, such as Staphylococcus aureus, Pseudomonas aeruginosa, and Listeria monocytogenes [14].. As biocontrol agents, phages have the following advantages over conventional antibiotics: high specificity, self-replication, self-limitation, continuous adaption to altered host systems, low inherent toxicity, and easy isolation. Phages have also been shown to effectively remove bacterial biofilms, including those of S. aureus, Streptococcus agalactiae, Escherichia coli, and other major pathogens that cause dairy cow mastitis [15-17]. In this study, a biofilm model was established in mammary-gland tissue to evaluate the removal of biofilms by SDQ [18]. We also investigated the stability and bactericidal activity of SDQ in detergents and other agents. The objective of this study were to investigate the potential utility of SDQ as a disinfectant to help control the mastitis and food contamination caused by $S$. aureus, to lay the foundation for the development of phage-based narrow-spectrum biological disinfectants.

\section{Results \\ Morphology and plaques of SDQ}

A S. aureus phage, designated vB_SauM_SDQ (abbreviated as SDQ), was isolated from sewage using $S$. aureus ATCC 43300 as the host strain. The plaque of SDQ is shown in Fig. 1a. Light-colored halo rings occur around the phage plaque, indicating that SDQ may secrete polysaccharide depolymerase to enhance its ability to lyse bacteria. Electron micrographic images of SDQ indicated that it has an isometric, icosahedral head, a long neck, and a contractile tail, suggesting that SDQ is a member of the family Myoviridae, as shown in Fig. 1b. The diameter of the SDQ head is approximately $75 \pm 3 \mathrm{~nm}(n=3)$, and the tail length is approximately $189 \pm 5 \mathrm{~nm}(\mathrm{n}=3)$.

\section{One-step growth curve}

The optimal multiplicity of infection (MOI) determination (Table 1 ) showed that $\mathrm{MOI}=0.01$ produced the highest phage production rate. Therefore, when constructing the one-step growth curve, the rates were determined at MOI $=0.01$. The one-step growth curve of SDQ infecting S. aureus ATCC 43300 revealed an eclipse period of $15 \mathrm{~min}$, a latent phase of $25 \mathrm{~min}$, and a
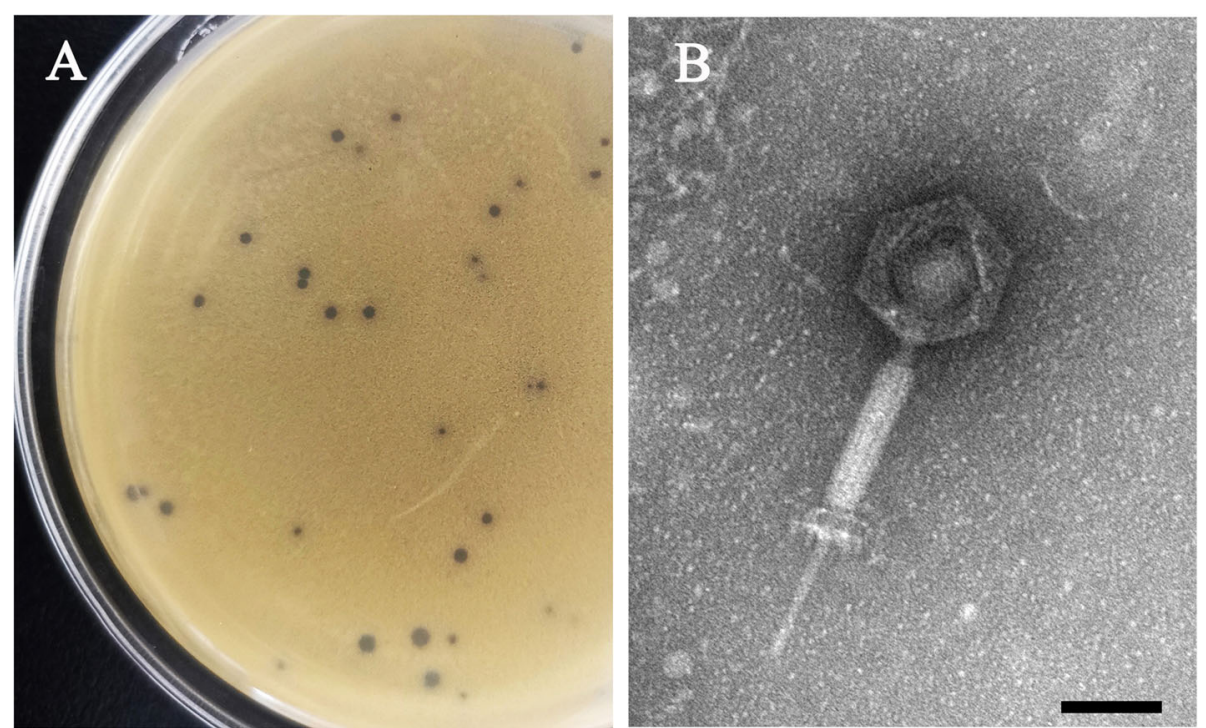

Fig. 1 Morphology and plaques of SDQ. a Phagocytic plaque of SDQ. b SDQ was negatively stained with 2\% phosphotungstic acid and examined with transmission electron microscopy at an accelerating voltage of $120 \mathrm{kV}$. The scale bar represents $50 \mathrm{~nm}$ 
Table 1 Determination of optimal multiplicity of infection (MOI)

\begin{tabular}{lllll}
\hline No. & Number of bacteria & Number of phages & MOI & Phage titers/(PFU/mL) \\
\hline 1 & $10^{6}$ & $10^{8}$ & 100 & $1.2 \times 10^{8} \pm 0.5 \times 10^{8}$ \\
2 & $10^{6}$ & $10^{7}$ & 10 & $2.5 \times 10^{8} \pm 0.5 \times 10^{8}$ \\
3 & $10^{6}$ & $10^{6}$ & 1 & $4.3 \times 10^{8} \pm 1.0 \times 10^{8}$ \\
4 & $10^{6}$ & $10^{5}$ & 0.1 & $2.3 \times 10^{9} \pm 0.7 \times 10^{9}$ \\
5 & $10^{6}$ & $10^{4}$ & 0.01 & $1.7 \times 10^{10} \pm 0.2 \times 10^{10}$ \\
6 & $10^{6}$ & $10^{3}$ & 0.001 & $5.4 \times 10^{9} \pm 0.9 \times 10^{9}$ \\
\hline
\end{tabular}

MOI The values indicate means and standard deviations (SD) $(n=3)$

burst size of $\sim 220$ plaque-forming units (PFU) per infected cell $\left(\left[2.2 \times 10^{7} \mathrm{PFU} / \mathrm{mL} \times 10 \mathrm{~mL}\right] /\left[10^{5} \mathrm{CFU} / \mathrm{mL} \times\right.\right.$ $10 \mathrm{~mL}])$, indicating that SDQ is an efficient lytic phage (Fig. 2).

\section{$\mathrm{pH}$ and thermal stability}

$\mathrm{pH}$ stability tests showed that SDQ is stable at $\mathrm{pH} 4.0-$ 11.0. At pH 3.0, SDQ activity decreased significantly, and at $\mathrm{pH} 12.0$ and $\mathrm{pH} 13.0$, no plaque formation was observed (Fig. 3a). SDQ showed 100\% stability at room temperature $\left(25^{\circ} \mathrm{C}\right)$ and refrigeration temperature $\left(4{ }^{\circ} \mathrm{C}\right)$, and also good stability after incubation at $37^{\circ} \mathrm{C}$ and $50{ }^{\circ} \mathrm{C}$ for $1 \mathrm{~h}$. Its activity gradually decreased at $60^{\circ} \mathrm{C}$ and it was totally inactive at $\geq 70{ }^{\circ} \mathrm{C}$ (Fig. 3b). SDQ also showed activity after storage at $4{ }^{\circ} \mathrm{C}$ for 6 months (Additional file 1: Table S1).

\section{Host range of SDQ}

To determine the host range of SDQ, 26 bacterial strains were used in plaque assays. SDQ showed lytic activity against most $S$. aureus strains, whereas no activity was observed against the other species tested in this study (Table 2 and Additional file 2: Table S2). These results indicate that SDQ is $S$. aureus-specific, with a broad lytic spectrum.

\section{Lytic efficiency of SDQ against planktonic bacteria}

The ability of SDQ to remove the planktonic form of methicillin-resistant S. aureus (MRSA) 25-4 was evaluated at various time points after its introduction $(2,4,6$, 8,10 , and $12 \mathrm{~h}$ ). The number of planktonic bacteria decreased with time, as shown in Fig. 4. Compared with the control group, the number of bacteria had decreased by $99 \%$ after $10 \mathrm{~h}$. After SDQ treatment for $12 \mathrm{~h}$, the bacterial suspension was clear, with a large amount of bacterial debris, and no viable bacteria were detected. The titer of SDQ increased by three orders of magnitude during this period.

\section{Biofilm sensitivity to SDQ}

SDQ showed strong antibiofilm activity in the process of destroying biofilms (Fig. 5). In the control group, the

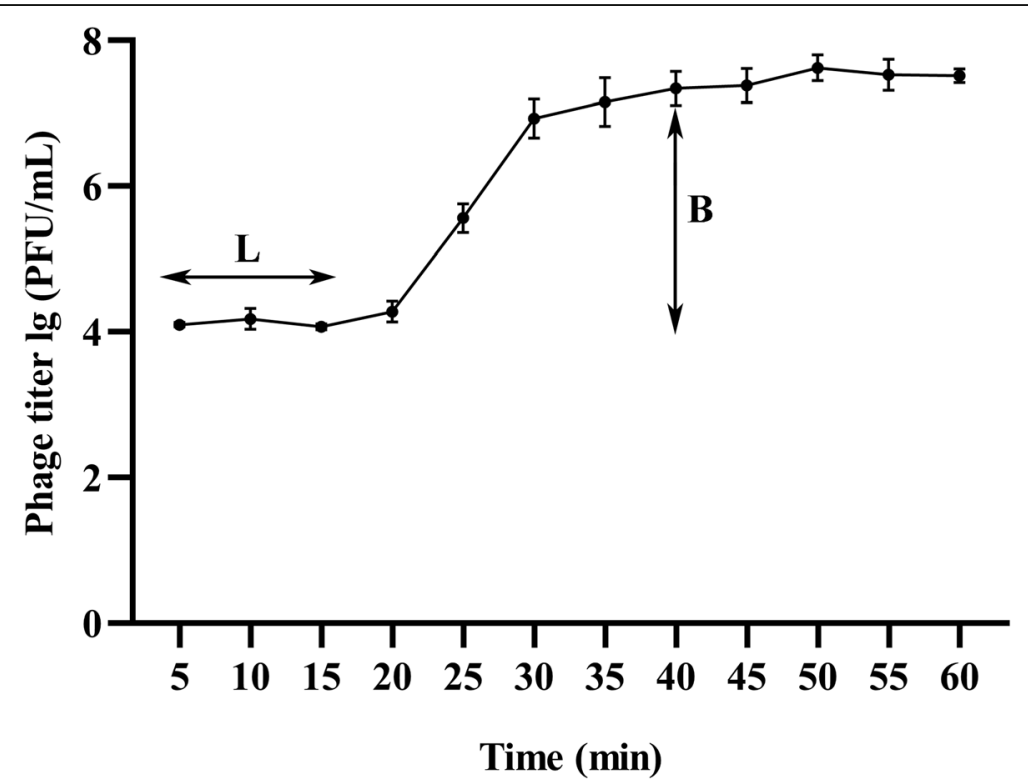

Fig. 2 One-step growth curve of SDQ. One-step phage growth of SDQ at $37^{\circ} \mathrm{C}$ was investigated. The phage growth parameters are indicated in the figure and correspond to: L, latent period and B, burst size. Data are presented as mean \pm SD of three independent experiments 


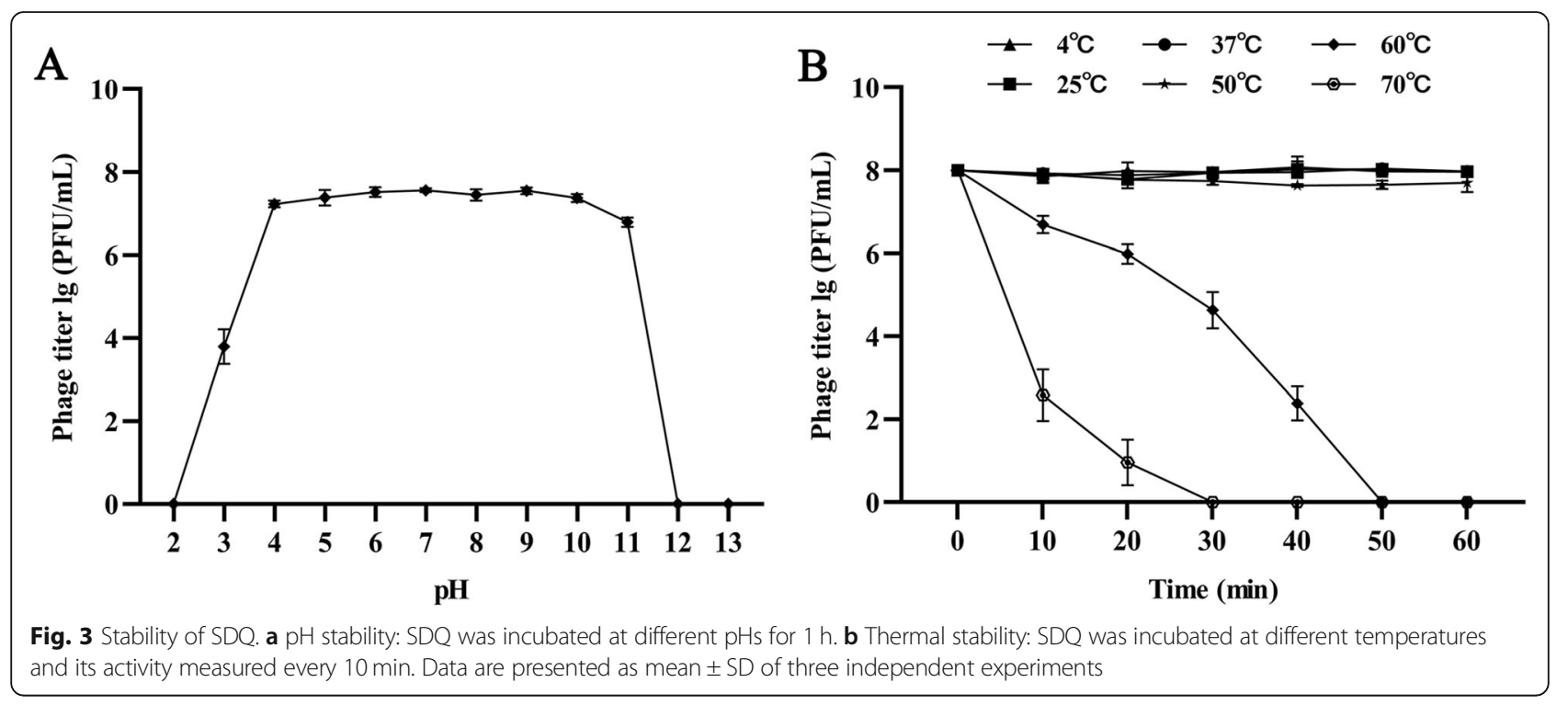

Table 2 Host range of SDQ against different clinical isolates of S. aureus

\begin{tabular}{|c|c|c|c|c|}
\hline Bacterial species & Strain & Phage Sensitivity & Strain Resource & MLST (ST) \\
\hline \multirow[t]{20}{*}{ S. aureus } & ATCC 43300 & + & ATCC & - \\
\hline & ATCC 29213 & + & ATCC & - \\
\hline & ATCC 25923 & + & ATCC & - \\
\hline & SA $2 Y 3-4$ & + & Clinical isolate & 97 \\
\hline & SA 2Y9-1 & + & Clinical isolate & 97 \\
\hline & SA 2Y7-1 & + & Clinical isolate & 5817 \\
\hline & SA 2Y4-3 & + & Clinical isolate & 239 \\
\hline & SA 7-1 & - & Clinical isolate & 398 \\
\hline & SA 7-3 & + & Clinical isolate & 398 \\
\hline & SA 8-1 & - & Clinical isolate & 1 \\
\hline & SA 8-2 & - & Clinical isolate & 2154 \\
\hline & SA 8-3 & - & Clinical isolate & 9 \\
\hline & SA 25-4 & + & Clinical isolate & 239 \\
\hline & SA $25-5$ & + & Clinical isolate & 97 \\
\hline & SA 27-2 & + & Clinical isolate & 5796 \\
\hline & SA $4-2 p$ & + & Clinical isolate & 5 \\
\hline & $S A-11-2-2 p$ & + & Clinical isolate & 398 \\
\hline & SA11-1 & + & Clinical isolate & 97 \\
\hline & SA11-2 & + & Clinical isolate & 97 \\
\hline & SA16b & + & Clinical isolate & 398 \\
\hline S. agalactiae & ATCC 13813 & - & ATCC & - \\
\hline L. monocytogenes & ATCC 19115 & - & ATCC & - \\
\hline E. faecalis & ATCC 29212 & - & ATCC & - \\
\hline S. Typhimurium & ATCC 14028 & - & ATCC & - \\
\hline P. mirabilis & CMCC 49005 & - & CMCC & - \\
\hline E. coli & ATCC 25922 & - & ATCC & - \\
\hline
\end{tabular}

$(+)=$ lytic; $(-)=$ non lytic 


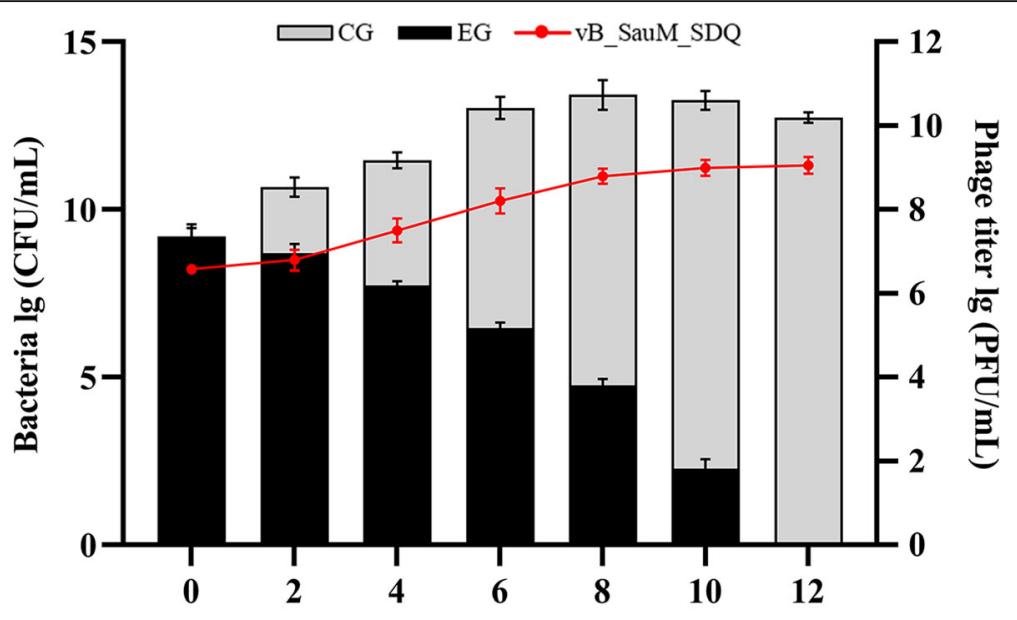

Time (h)

Fig. 4 Activity of SDQ against S. aureus. The Black histogram shows the removal of bacteria by SDQ (experimental group, EG); the gray histogram shows the changes in phage-untreated bacteria (control group, CG); line graph shows the changes in the SDQ titer. Data are presented as mean \pm SD of three independent experiments

concentration of SA $25-4$ in the biofilm was $1.89 \times 10^{5}$ $\mathrm{CFU} / \mathrm{mL}$, but as the SDQ treatment time increased, the number of bacteria in the biofilm decreased. Compared with the control group, the bacterial concentration in the biofilm decreased by $9.54 \times 10^{4} \mathrm{CFU} / \mathrm{mL}(50 \%)$, $1.67 \times 10^{5} \mathrm{CFU} / \mathrm{mL}(88 \%)$, and $1.81 \times 10^{5} \mathrm{CFU} / \mathrm{mL}$ (95\%) at 4,24 , and $48 \mathrm{~h}$, respectively, indicating that SDQ effectively removed the biofilm. After crystal violet staining, the measured absorbance $\mathrm{OD}_{600}$ was reduced from 0.98 to 0.25 , confirming that SDQ effectively removed the biofilm. SDQ not only effectively removed an already-formed biofilm, but also prevented the formation of a bacterial biofilm (Additional file 3: Table S3). Therefore, SDQ both effectively prevents and removes bacterial biofilms.

Fluorescence microscopy and scanning electron microscopy (SEM) observations showed that SA 25-4 formed a dense biofilm structure on glass coverslips (Fig. 6a, d). After SDQ treatment for $24 \mathrm{~h}$, the bacterial density in the biofilm had decreased significantly (Fig. $6 \mathrm{~b}, \mathrm{e})$. After SDQ treatment for $48 \mathrm{~h}$, the integrity of the bacterial biofilm structure was destroyed (Fig. 6c, f),

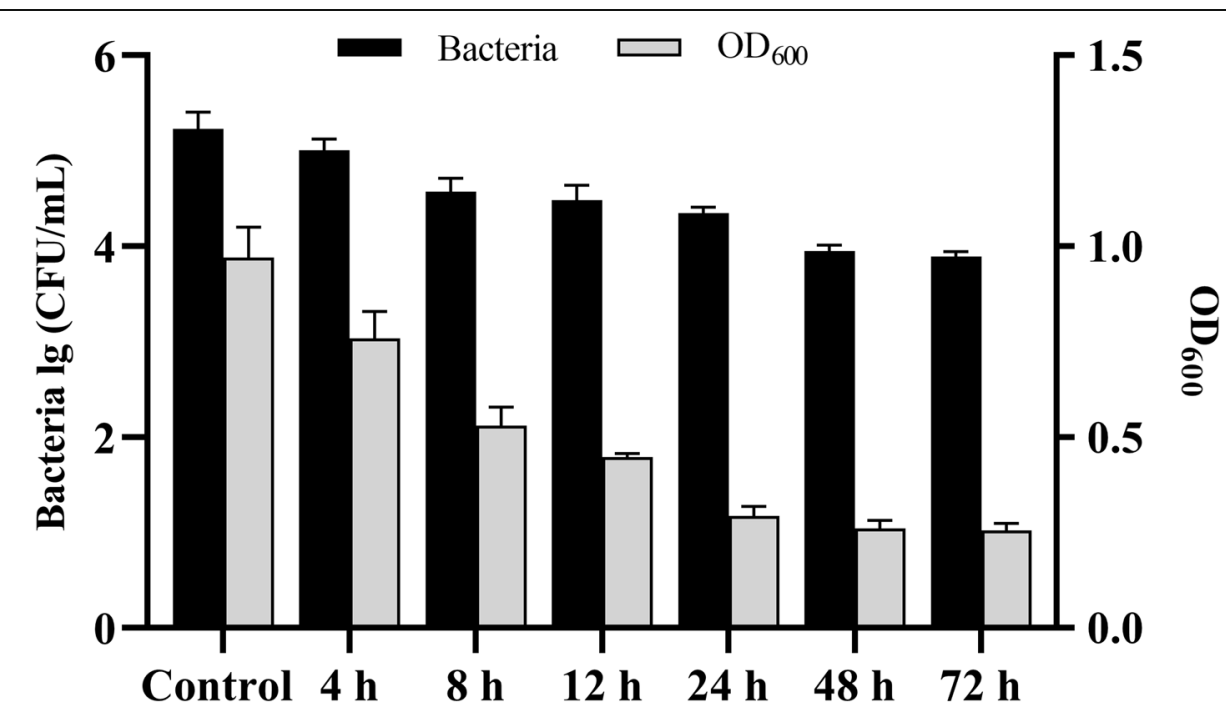

Fig. 5 Reduction in established S. aureus biofilm after challenge with SDQ for 4, 8, 12, 24, 48, or $72 \mathrm{~h}$. The black histogram shows the removal of bacteria in the biofilm by SDQ; the gray histogram shows the removal of biofilm by SDQ. Data are presented as mean \pm SD of three independent experiments 


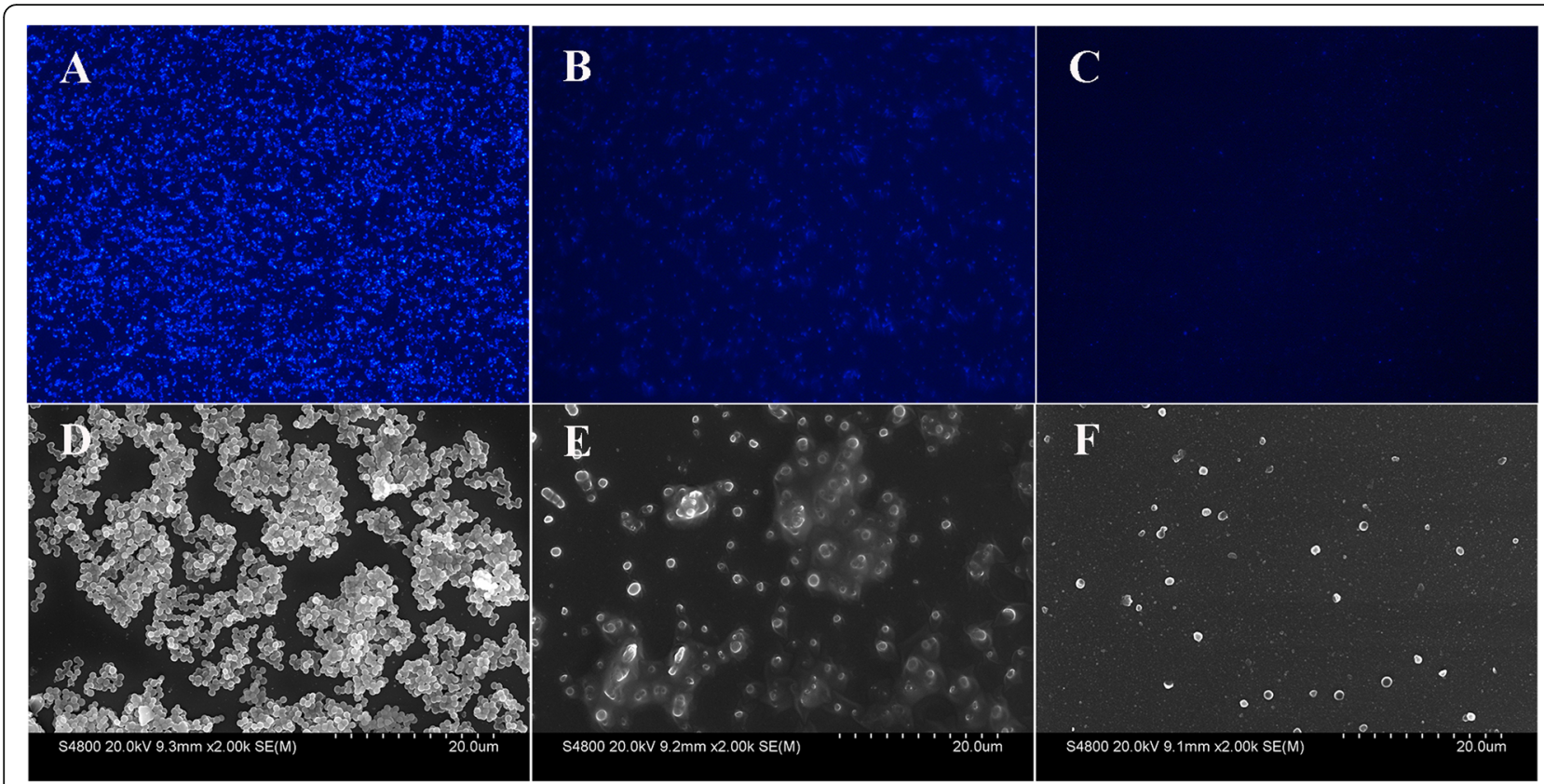

Fig. 6 Observation of biofilms with fluorescence microscopy and SEM. a, b, c Fluorescence microscopic observations at 0, 24, and 48 h, respectively (200X). D, E, F SEM observations at 0, 24, and $48 \mathrm{~h}$, respectively. The numbers of bacteria in the biofilms were significantly reduced at $24 \mathrm{~h}$ and $48 \mathrm{~h}$ after SDQ treatment

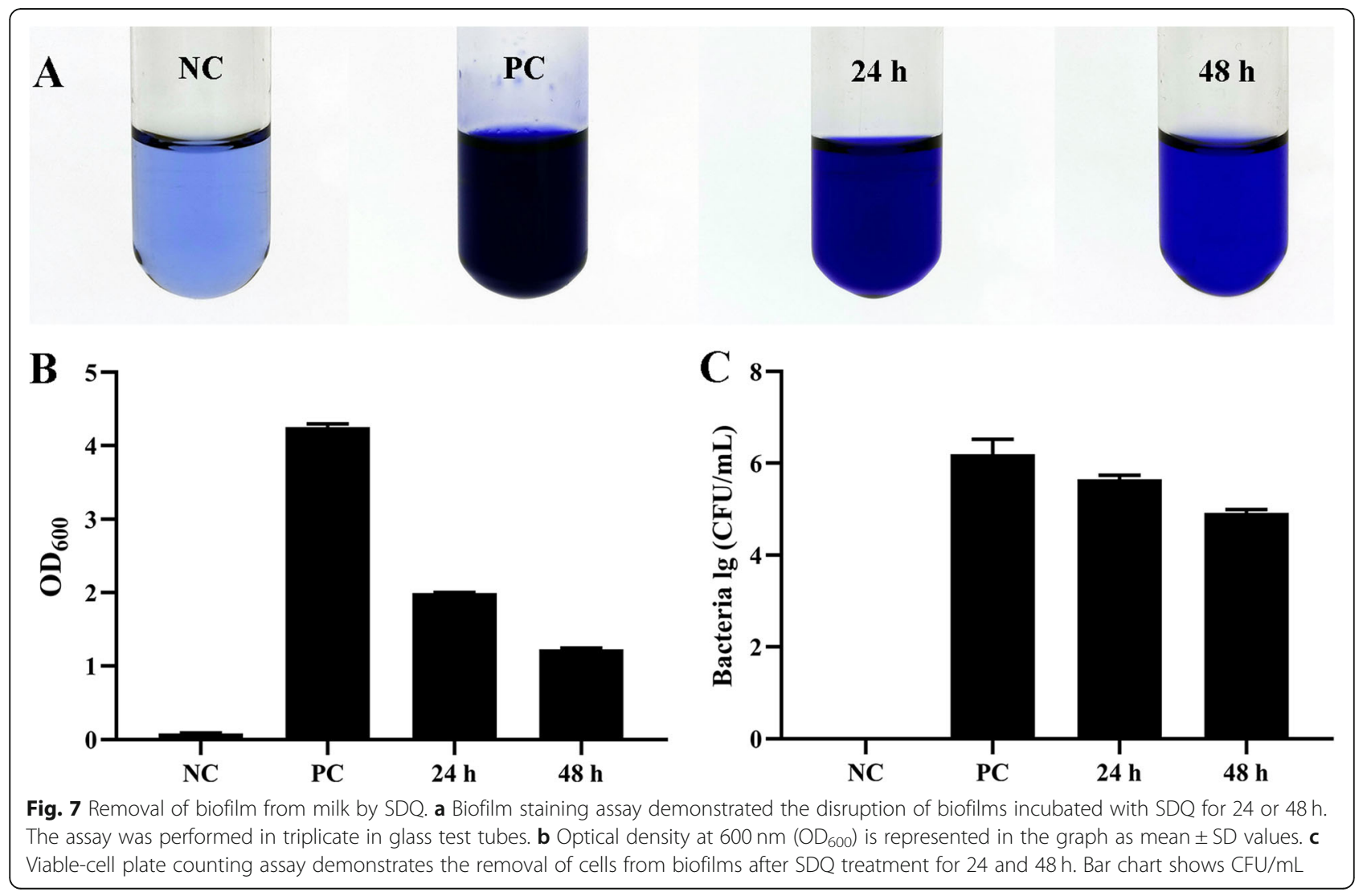


indicating that SDQ has a strong capacity to kill bacteria and destroy the biofilm structure.

\section{Removal of biofilm from milk by SDQ}

SDQ showed strong antibiofilm activity when destroying biofilms in milk (Fig. 7). Crystal violet staining showed that after treatment with SDQ for $24 \mathrm{~h}$, the $\mathrm{OD}_{600}$ decreased from 4.21 to 1.95 (by $54 \%$ compared with the positive control group), and at $72 \mathrm{~h}$, the $\mathrm{OD}_{600}$ had decreased by 3.02 units (71\%) (Fig. 7a, b), indicating that SDQ effectively removed the biofilm from milk. In the positive control group, the concentration of SA 25-4 in the biofilm was $1.57 \times 10^{6} \mathrm{CFU} / \mathrm{mL}$, but as the SDQ treatment time increased, the number of bacteria in the biofilm decreased. Compared with the positive control group, the bacterial concentration in the biofilm at $24 \mathrm{~h}$ had decreased by $1.09 \times 10^{6} \mathrm{CFU} / \mathrm{mL}(69 \%)$, and at $48 \mathrm{~h}$, the bacterial concentration had decreased by $1.48 \times 10^{6}$ CFU/mL (95\%) (Fig. 7c), confirming that SDQ effectively removed the biofilm from milk.

\section{SDQ treatment of S. aureus biofilm formed in mammary- gland tissue}

SDQ not only destroyed the biofilm in mammary-gland tissue, but also prevented its formation, thus showing strong antibiofilm activity (Fig. 8). After $72 \mathrm{~h}$, the bacterial concentration had decreased from $3.28 \times 10^{6} \mathrm{CFU} / \mathrm{mL}$ to $3.95 \times 10^{4} \mathrm{CFU} / \mathrm{mL}$, and the number of bacteria in the biofilm had decreased by $98 \%$, indicating the clear removal of the biofilm, and the concentration of SDQ increased from $9.15 \times 10^{6} \mathrm{PFU} / \mathrm{mL}$ to $3.52 \times 10^{8} \mathrm{PFU} / \mathrm{mL}$. Therefore, the maintenance of a high phage concentration contributed to the continuous removal of the biofilm.
Effects of detergents and environmental factors on SDQ To determine whether detergents affect the bactericidal efficacy of SDQ, the phage was tested in combination with detergents or under the harsh conditions that might occur during its application. SDQ was mixed with SA 25-4 in the presence of various compounds, and the biofilm was monitored with the plaque assay to determine the lytic activity of SDQ relative to the control. If the detergents did not inactivate the phage, they were expected to eliminate the biofilm because they disperse organic matter from surfaces. Various detergents (1\% final concentration) were used with the phage to determine whether their addition improved the bactericidal efficacy of SDQ.

Notably, as shown in Fig. 9, an anionic detergent (sodium dodecyl sulfate, SDS) inactivated SDQ, whereas hexadecyl trimethyl ammonium bromide (CTAB) and ethylenediaminetetraacetic acid (EDTA) significantly reduced the activity of SDQ. However, SDQ retained its full activity in zwitterionic (CHAPS) and nonionic detergents (Triton X-100, Tween 20, and Brij 35). SDQ was also tested in 10\% fetal bovine serum, which represents an organic soil load, as defined by the Association of Official Analytical Chemists (AOAC) [19]. Under organic load conditions, SDQ was as active as the control. SDQ was then dialyzed against distilled water and tested in the absence of any buffer. Compared with the control, SDQ retained its full activity.

To identify the synergistic effects of SDQ and detergents, established biofilms were treated with SDQ, Triton X-100, or a combination of SDQ and Triton X-100. As shown in Fig. 10, compared with SDQ, Triton X-

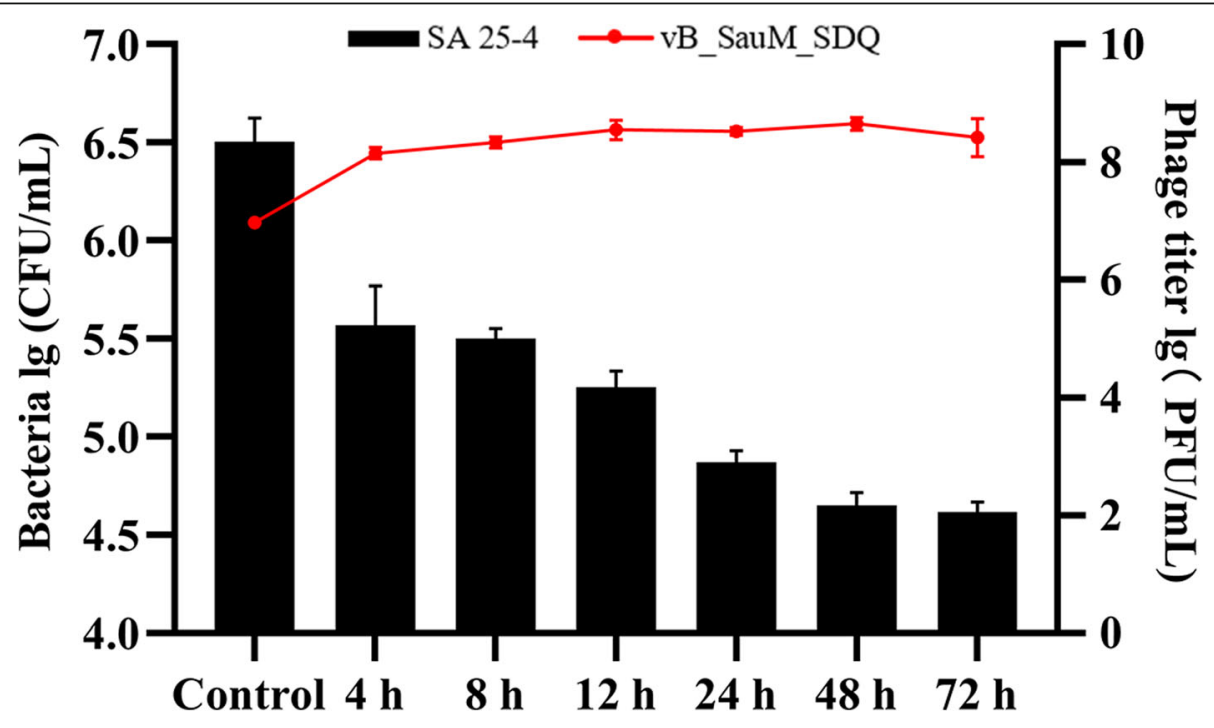

Fig. 8 Removal of biofilm from mammary-gland tissue by SDQ. The histogram shows the removal of bacteria from the biofilm by SDQ; line graph shows the changes in the SDQ titer. Data are presented as mean \pm SD of three independent experiments 


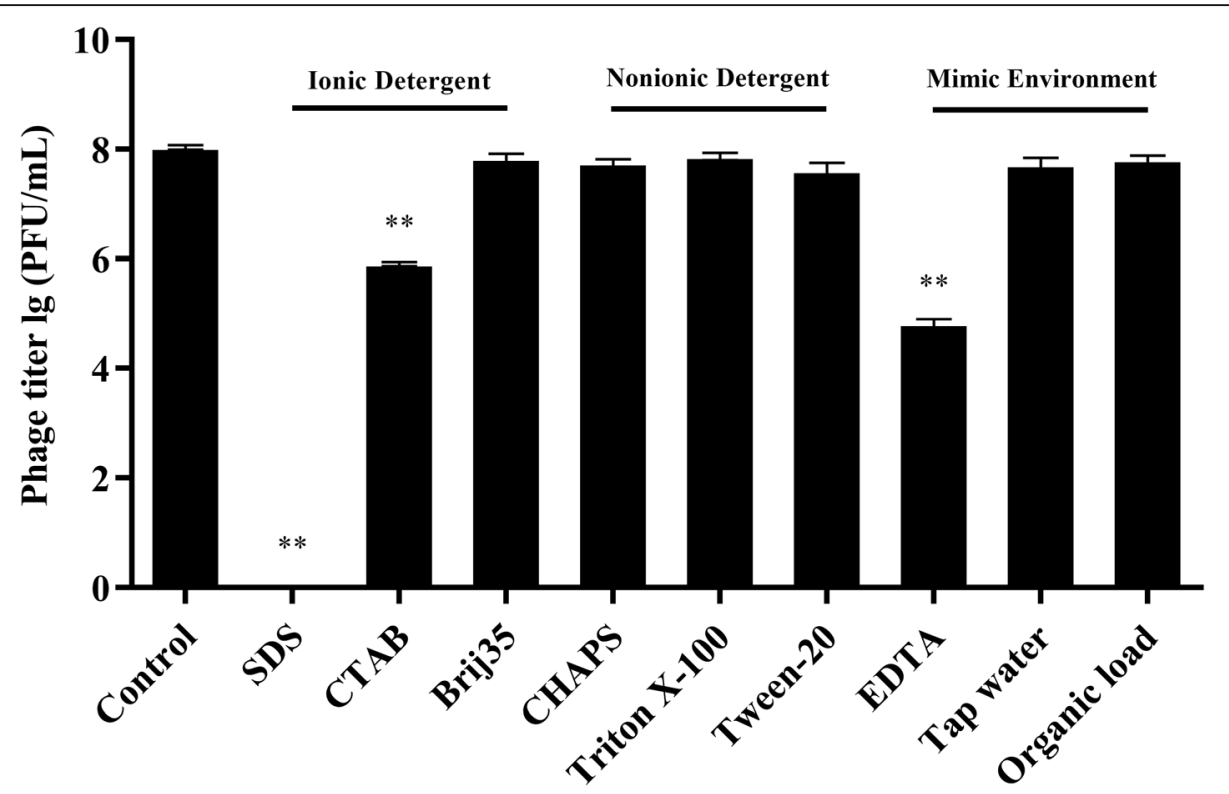

Fig. 9 SDQ activity in the presence of detergents and environmental factors. SDQ was tested against S. aureus in the presence of $1 \%$ detergent (SDS [anionic], CTAB [cationic], CHAPS [zwitterionic], Triton X-100, Tween 20, and Brij 35 [all nonionic]), 10 mM EDTA, tap water, or 10\% organic material (fetal bovine serum) with the plaque assay. Data are presented as mean \pm SD of three independent experiments

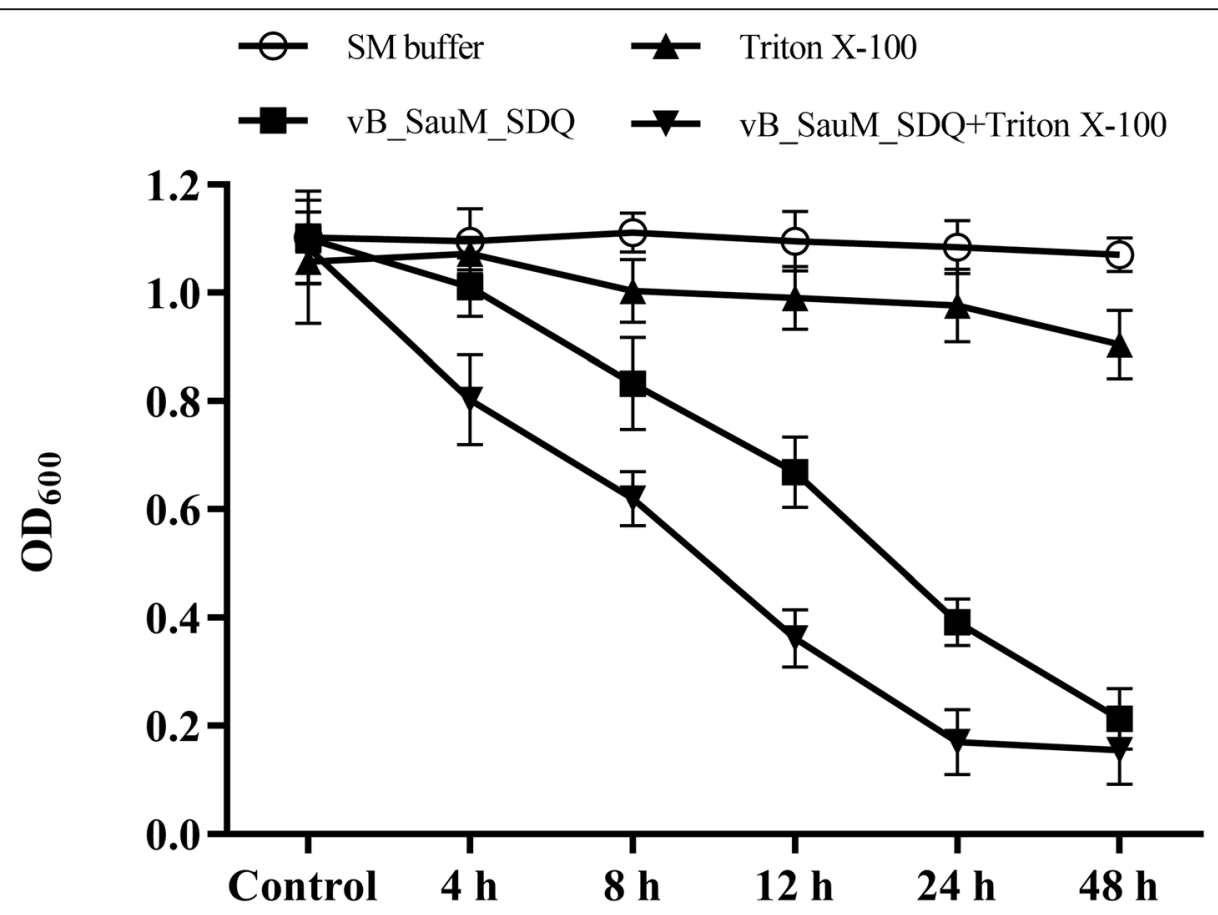

Fig. 10 Synergistic effects of SDQ and detergent on biofilm. At the indicated times, the numbers of cells in biofilm treated with SM buffer (black circles), VB_SauM_SDQ (black squares), Triton X-100 (black triangles), or vB_SauM_SDQ + Triton X-100 (black inverted triangles) were determined by the optical density at $600 \mathrm{~nm}$. Data are presented as mean \pm SD of three independent experiments 
$100+$ SDQ significantly reduced the mass of the SA $25-$ 4 biofilm within $12 \mathrm{~h}$.

\section{Discussion}

Staphylococcus aureus is one of the commonest causative agents of chronic mastitis. It can form biofilms and is therefore difficult to completely remove once established. Dairy cow mastitis caused by $S$. aureus does not respond well to antibiotic therapy, and infected cows must be segregated or culled from the herd. Therefore, effective preventive measures to eliminate the source of infection are very important [9]. Bacteriophage prophylaxis is a possible alternative strategy to achieve this goal. We studied the biological characteristics of SDQ and analyzed its ability to prevent and control biofilm formation. Our results showed that SDQ effectively prevented and controlled planktonic $S$. aureus bacteria and $S$. aureus biofilms. Therefore, it has potential utility as a disinfectant to control the mastitis and food contamination caused by S. aureus.

SDQ has been identified as a virulent phage with strong lytic efficacy against MRSA. It can reduce the MRSA concentration in culture medium to below the detection limit within $12 \mathrm{~h}$, indicating that it has potentially applicable in the treatment of clinical infections. However, the thermal stability and acid-base properties are the foundations of phage use in the clinical context [20]. In this study, SDQ was stable at $<50^{\circ} \mathrm{C}$ and within the range of conventional pHs (4-11). The temperature of the dairy cow feeding environment usually does not exceed $24^{\circ} \mathrm{C}$, whereas the normal temperature range of dairy cows is $37.5-39.5^{\circ} \mathrm{C}$, so it is unlikely that SDQ will lose its activity in response to excessive temperature variations during its use. The $\mathrm{pH}$ range of fresh milk is 6.46.6, indicating that SDQ should be stable in milk. Furthermore, the titer of SDQ remains stable for more than 6 months at $4{ }^{\circ} \mathrm{C}$, which is convenient for storage. SDQ also multiplies during its sterilization of $S$. aureus. Phage self-replication is an important parameter that allows phages to be used as both antibacterial agents and protective or preservative agents in food to control the growth of foodborne pathogens in the food industry. Bacteriophage products are already in use in agricultural, food safety, and diagnostic applications, confirming the utility and viability of this approach. In this study, bacteriophage SDQ showed lytic activity against both $S$. aureus clonal complexes CC97 and CC398, and part of clonal complex CC1 strain (Additional file 2: Table S2). In the treatment of anti-phage bacterial strains and drug-resistant bacterial strains, phage can be used in combination with antibiotics, antimicrobial peptides, and other antibacterial drugs or in a phage cocktail to control resistant bacterial strains. Staphylococcus aureus SA 25-4 belongs to the CC97 strain, which is one of the main branches of ruminant-adapted $S$. aureus, so the results presented here are representative. All its characteristics strongly suggest that SDQ is a potential preventative and/or therapeutic bacteriophage that can be used against MRSA infections in ruminants.

Most infections are associated with biofilm formation [8]. Biofilms are recognized as a significant problem in many industries, including the medical and food industries, and also pose a threat to the environment [21-23]. Biofilm-forming $S$. aureus strains are generally much more difficult to kill and are more resistant to antimicrobial agents than their planktonic counterparts [24]. Previous studies have demonstrated that phages can potentially remove and/or disrupt $S$. aureus biofilms. Morris et al. showed that phages are more effective than antibiotics in biofilm removal $[25,26]$, and Alves et al. demonstrated that phage $\mathrm{K}$ disrupts the integrity of biofilms [27]. In this study, we evaluated the ability of SDQ to remove biofilm from polystyrene plastic plates, glass coverslips, milk, and mammary tissues. Bovine mammary tissue contains many mammary ducts and mammary alveoli. The biofilms on mammary tissue are more complex than those on polystyrene or glass and are therefore closer to the actual situation in cows. Therefore, in this experiment, we used the method of the Milho et al. (2019) to establish an in vitro model of isolated mammary-gland tissue in which to evaluate the effect of SDQ on the S. aureus biofilm [18]. The number of bacteria in the biofilm decreased significantly after SDQ treatment. Fluorescence microscopy and SEM showed that the integrity of the biofilm structure was destroyed after SDQ treatment. SDQ also removed $S$. aureus biofilm from milk. In summary, SDQ effectively removed biofilms from polystyrene, glass, milk, and mammary-gland tissues. Consistent with previous research results, our findings show that SDQ has potential utility in the prevention and treatment of bovine mastitis $[28,29]$. SDQ formed plaques surrounded by a halo, indicating that this phage expresses polysaccharide depolymerase, an enzyme that may enhance the antibiofilm activity of phages [30,31]. Although SDQ does not have the broad-spectrum bacteriocidal activity common to most disinfectants, it has advantages that make it superior to common disinfectants in this context. The bacteriophage is nontoxic to livestock or humans and is environmentally safe, noncorrosive, economic, and easy to obtain. Therefore, SDQ can be used as a "biological disinfectant" or environmental bactericide capable of controlling S. aureus biofilms.

However, inhibitors maybe encountered during its practical application, such as detergents, organic material, etc. Disinfectants are often used in conjunction with detergents. Detergents permeate, disperse, and remove smudges from surfaces, thereby allowing disinfectants to 
work. However, the activity of disinfectants is often reduced or they are inactivated by detergents [32]. In this study, we examined the effect of detergents on the bactericidal efficacy of SDQ. Ionic detergents reduced the activity or inactivated SDQ, but these are seldom used as cleaning agents, whereas SDQ maintained full bacteriolytic activity in the presence of nonionic detergents (Triton X-100, Tween 20, and Brij 35). In practice, nonionic detergents have good emulsification, penetration, and dispersion properties, rendering them effective detergents [33-35]. Therefore, these detergents can assist SDQ to disrupt the $S$. aureus biofilms.

According to the AOAC, $10 \%$ fetal bovine serum represents an organic soil load [19]. To test the practical effectiveness of SDQ, it was diluted with tap water and tested in the absence of any buffer. Compared with the control, the full activity of SDQ was retained in both tap water and fetal bovine serum. In some region, problems such as hard water might be encountered, which can bind to either disinfectants or detergents, interfering with their effectiveness [36]. Metal chelators, such as EDTA, are commonly used to treat hard water. However, the addition of $10 \mathrm{mM}$ EDTA did not reduce the lytic activity of SDQ for $S$. aureus cells. Therefore, the use of this phage combined with a nonionic detergent can better eliminate a biofilm than the biofilm alone and is unaffected by organic matter or tap water.

\section{Conclusions}

In this study, SDQ not only prevented and removed $S$. aureus biofilms, but also multiplied during the process of infection, making it a good candidate for further preventative and therapeutic development. SDQ also retained its full activity in the presence of nonionic detergents, tap water, a metal chelator, and organic material, and can be used in combination with detergents. Although bacteriophage will never replace traditional disinfectants, they have great potential utility as narrowspectrum biological disinfectants for controlling S. aureus infections and the devastating effects of MRSA and related biofilms, such as occur on medical equipment and in the food industry and livestock farming.

\section{Methods}

\section{Bacterial strains and culture conditions}

A selection of 26 different bacterial strains, including $S$. aureus, Streptococcus agalactiae, Enterobacter faecalis, Salmonella typhimurium, Proteus mirabilis, Listeria monocytogenes, and E. coli, were purchased from the American Type Culture Collection (ATCC, Manassas, VA, USA) and the National Center for Medical Culture Collections (CMCC, Beijing, China), and 17 clinical $S$. aureus isolates were provided by Heilongjiang Provincial Key Laboratory for the Prevention and Control of Bovine
Diseases (Daqing, Heilongjiang, China). These clinical strains were tested with PCR amplification of the mecA gene to confirm that the isolates were MRSA. We identified the multilocus sequence typing (MLST) types of these strains, and the 17 clinical strains of $S$. aureus included nine ST types (Additional file 2: Table S2). All the strains were streaked on tryptic soy agar (Hopebio, Qingdao, China) before experimentation, and single colonies were recovered by culture in tryptic soy broth (Hopebio) overnight at $37^{\circ} \mathrm{C}$ to ensure the purity of the bacterial stocks. All bacterial strains were preserved in $20 \%(\mathrm{v} / \mathrm{v})$ glycerol and the stocks were maintained at $-80^{\circ} \mathrm{C}$.

\section{Biological characteristics of the phage Isolation of the $S$. aureus phage}

Phage SDQ was isolated from a dairy farm sewage system using $S$. aureus subsp. aureus Rosenbach (ATCC $43300)$ as the host strain. Sewage samples were collected from a cattle farm sewer system (Daqing, Heilongjiang, China), centrifuged $\left(9000 \times \mathrm{g}, 4{ }^{\circ} \mathrm{C}, 10 \mathrm{~min}\right)$, and filtered through $0.22 \mu \mathrm{m}$ membrane filters (SteriFlip, Millipore). The filtered raw sewage $(100 \mathrm{~mL})$ was placed in sterile $100 \mathrm{~mL}$ flasks with double-strength TSB. S. aureus ATCC 43300 and the prepared sewage samples were then cocultured overnight at $37^{\circ} \mathrm{C}$. The cocultures were centrifuged at $10,000 \times \mathrm{g}$ for $10 \mathrm{~min}$ at $4{ }^{\circ} \mathrm{C}$, and the supernatants were collected and filtered $(0.22 \mu \mathrm{m})$. A double-layer agar plate assay was used to detect and purify the phage from the supernatant [37]. Briefly, we picked a single spot from a double-layer plate and $100 \mu \mathrm{L}$ of the host strain and mixed them with $5 \mathrm{~mL}$ of molten soft agar $(0.75 \%)$ medium. This was then overlain on the surface of solidified basal Luria-Bertani (LB) agar. The sample was then incubated for $6-8 \mathrm{~h}$ at $37^{\circ} \mathrm{C}$. This was repeated three times to obtain the purified phage lysate. The purified phage was then amplified and stored in dimethyl sulfoxide (DMSO, 3:1 [v/v]) at either $4{ }^{\circ} \mathrm{C}$ or $-80^{\circ} \mathrm{C}$.

Following large-scale culture, SDQ was precipitated with $10 \%(\mathrm{w} / \mathrm{v})$ polyethylene glycol (PEG) 8000 and $1 \mathrm{M}$ $\mathrm{NaCl}$. The phage sample was then placed on the top of a discontinuous $\mathrm{CsCl}$ gradient $(1.32,1.45,1.50$, and $1.70 \mathrm{~g} /$ $\mathrm{mL}$ ) and centrifuged at $35,000 \times \mathrm{g}$ for $3 \mathrm{~h}$ at $4{ }^{\circ} \mathrm{C}$. The phage band was collected and dialyzed against a suspension medium (SM) buffer $(0.01 \%$ gelatin, $100 \mathrm{mM} \mathrm{NaCl}$, $50 \mathrm{mM}$ Tris- $\left.\mathrm{HCl}, 10 \mathrm{mM} \mathrm{MgSO}_{4}\right)$ at $4{ }^{\circ} \mathrm{C}$.

\section{Morphology of SDQ}

The morphology of SDQ was examined with transmission electron microscopy (TEM; JEM-2100, JEOL, Tokyo, Japan). SDQ was purified and transferred to carbon-coated copper film for $1 \mathrm{~min}$ and negatively stained with $2 \%$ phosphotungstic acid ( $\mathrm{pH} 7.0$ ). The excess liquid was removed, and the sample air-dried on 
the carbon-coated copper grid. The stained SDQ was observed under TEM $(120 \mathrm{kV})$.

\section{One-step growth}

'MOI' refers to the ratio of the phage to the host bacteria during the processes of infection [38]. S. aureus ATCC 43300 was grown to logarithmic phase and transferred into fresh LB broth at a final concentration of $10^{7} \mathrm{CFU} /$ $\mathrm{mL}$. SDQ was then added at different MOIs (phage/bacteria $=0.001,0.01,0.1,1,10$, or 100) and the mixtures were incubated for $8 \mathrm{~h}$. Immediately after serial dilution, the phage titer in each sample was determined with the double-layer agar plate method.

To construct the one-step growth curve, SDQ was added to an exponential-phase culture of $S$. aureus $(1 \times$ $10^{5} \mathrm{CFU} / \mathrm{mL}$ ) at an MOI of 0.01 and allowed to adsorb for $10 \mathrm{~min}$ at $37^{\circ} \mathrm{C}$. The mixture was then centrifuged at $12,000 \times \mathrm{g}$ for $5 \mathrm{~min}$ at $4{ }^{\circ} \mathrm{C}$, and the pellet was resuspended in $10 \mathrm{~mL}$ of LB broth. The suspension was then incubated at $37^{\circ} \mathrm{C}$ with shaking at $180 \mathrm{rpm}$. The sample was collected at $5 \mathrm{~min}$ intervals until $60 \mathrm{~min}$. The phage titer of the lysates was quantified with the double-layer agar plate method and the growth curve for SDQ was constructed from these data [39]. The experiments were performed in triplicate.

\section{$\mathrm{pH}$ and thermal stability}

To measure the stability characteristics of SDQ, its survival rate was determined after treatment with diverse ranges of $\mathrm{pHs}$ and temperatures. Briefly, for the $\mathrm{pH}$ stability test, SDQ was incubated at $\mathrm{pH} 2.0,3.0,4.0,5.0,6.0$, 7.0, 8.0, 9.0, 10.0, 11.0, 12.0, and 13.0 for $1 \mathrm{~h}$ at $37^{\circ} \mathrm{C}$. For the thermal stability test, SDQ was incubated at 4 , $25,37,50,60$, and $70^{\circ} \mathrm{C}$, and the phage titers were measured every $10 \mathrm{~min}$. After treatment, all the samples were diluted and tested immediately with the double-layer agar plate method. To test SDQ stability after long-term storage, aliquots of phage suspensions were stored at $4{ }^{\circ} \mathrm{C}$ for 6 months. All the experiments were performed in triplicate.

\section{Antimicrobial activity of SDQ \\ Determination of SDQ the host range}

The host range of SDQ was determined with spot tests against a panel of 21 strains [40]. In the spot test experiment, $100 \mu \mathrm{L}$ droplets of phage stock $\left(10^{9}\right.$ $\mathrm{PFU} / \mathrm{mL}$ ) were spotted onto freshly seeded lawns of the indicated bacterial strains. The production of lytic spots was assessed after incubation for $12 \mathrm{~h}$ at $37^{\circ} \mathrm{C}$. The details of the bacterial strains used in the study are listed in Table 2.

\section{Lytic efficiency of SDQ against planktonic bacteria}

The experimental strain to be tested (SA 25-4) was grown overnight in LB broth. The overnight bacterial culture $(100 \mu \mathrm{L})$ was diluted in LB broth to a final titer of approximately $10^{9} \mathrm{CFU} / \mathrm{mL}$. SDQ was added at an MOI of 0.01 and incubated at $37^{\circ} \mathrm{C}$ with shaking at 180 $\mathrm{rpm}$ in an incubator. The colonies in the culture broth were counted at different time points $(0,2,4,6,8,10$, and $12 \mathrm{~h}$ ), and a phage-free treatment was used as the control. The bacterial count was calculated from the number of colonies on the plate. The change in phage titer was determined with the double-layer agar plate method [41]. All the experiments were performed in triplicate.

\section{Antibiofilm activity of SDQ Phage treatment of S. aureus biofilm in 96-well cell culture plates}

A 96-well cell culture plate was used to detect the inhibitory effect of SDQ on biofilm formation at $\mathrm{MOI}=$ 0.01 , and to investigate the removal of the biofilm by SDQ. In each well of a 96-well cell culture plate, TSB was inoculated with SA 25-4 at a final concentration of $10^{6} \mathrm{CFU} / \mathrm{mL}$. For the biofilm formation inhibition experiment, SDQ was added to the bacterial culture to a final titer of $10^{4} \mathrm{PFU} / \mathrm{mL}$, and incubated statically at $37^{\circ} \mathrm{C}$ for $48 \mathrm{~h}$. For the biofilm removal experiment, SA 25-4 was initially incubated under the conditions described above for $48 \mathrm{~h}$ to allow biofilm formation, and then treated with SDQ at a final titer of $10^{7} \mathrm{PFU} / \mathrm{mL}$ for $4,8,12,24,48$, or $72 \mathrm{~h}$. A phage-free treatment was used as the control. Viable-cell plate counting was used to determine the numbers of bacteria in the biofilms at different time points, and biofilm removal was measured with crystal violet staining. Each well was rinsed five times with sterile phosphate-buffered saline (PBS) and allowed to air-dry. The SDQ-treated biofilm in each well was stained with 5\% crystal violet solution (Becton Dickinson, Sparks, MD) at $25^{\circ} \mathrm{C}$ for $60 \mathrm{~min}$, eluted with $33 \%$ acetic acid, and the $\mathrm{OD}_{600}$ measured with a spectrophotometer (Beijing Purkinje General Instrument Co, Beijing, China) [42]. All the experiments were performed in triplicate.

\section{Microscopic imaging of biofilms}

The effects of SDQ on the biofilms were assessed with Hoechst 33342 stain (Beyotime Biotechnology, Shanghai, China) and visualized with fluorescence microscopy (Ti2, Nikon Corporation, Japan). Bacterial biofilms were grown on glass coverslips as described above. The nonadherent cells were removed and the wells were washed three times with sterile PBS. The biofilms were treated with SDQ at a final titer of $10^{7} \mathrm{PFU} / \mathrm{mL}$ for 0,24 , or 48 $h$. The glass coverslip was then washed once with sterile 
PBS. The biofilm was stained with Hoechst 33342 according to the manufacturer's protocol and visualized with fluorescence microscopy.

For DSEM, the biofilms were cultured as for fluorescence microscopy. The glass coverslips were washed once with sterile PBS. Each biofilm was immobilized with $5 \%$ glutaraldehyde, dehydrated a graded series of ethanol concentrations (20,50, 70, 90, and 100\%), and then freeze-dried before SEM analysis (Hitachi S-4800; Hitachi High-Technologies Europe GmbH, Krefeld, Germany).

\section{Removal of biofilm from milk by SDQ}

To study the removal of biofilm from milk by SDQ, we used pasteurized milk as the culture medium for the $S$. aureus biofilm. In this experiment, a constant temperature oscillator was used to keep the milk in a flowing state while the biofilm was cultured in a glass test tube. A logarithmic-growth-phase culture of SA 25-4 at a final concentration of $10^{6} \mathrm{CFU} / \mathrm{mL}$ was added to $1 \mathrm{~mL}$ of milk and cultured at $37^{\circ}$ and $120 \mathrm{rpm}$ for $48 \mathrm{~h}$. The nonadherent cells were removed by washing the biofilm three times with sterile PBS. SDQ at a final titer of $10^{7} \mathrm{PFU} / \mathrm{mL}$ was added for 24 or $48 \mathrm{~h}$. A phage-free treatment was used as the positive control, and milk was used as the negative control to compare the removal of the biofilm by the phage. The number of bacteria in the biofilm at different time points was determined with viable-cell plate counting, and biofilm removal was measured with crystal violet staining. Each sample was rinsed five times with sterile PBS and allowed to air-dry. The SDQ-treated biofilms in each sample were stained with $0.5 \%$ crystal violet solution (Becton Dickinson) for $60 \mathrm{~min}$ at $25^{\circ} \mathrm{C}$ and eluted with $33 \%$ acetic acid. The $\mathrm{OD}_{600}$ of the eluate was measured with a spectrophotometer (Beijing Purkinje General Instrument Co.). All the experiments were performed in triplicate.

\section{Phage treatment of S. aureus biofilm formed in mammary gland tissue}

The animal trial in this study was approved by the Institutional Animal Care and Use Committee (IACUC) of Heilongjiang Bayi Agricultural University, and conventional animal welfare regulations and standards were followed. A mammary gland from a healthy dairy cow was obtained from a local farm. The mammary gland was immediately sterilized with a previously described method [43]. Briefly, the mammary gland was washed with saline for $10 \mathrm{~min}$, and then placed in alcohol (75\%) for 2-3 min. This was repeated twice. The gland was placed in a desiccator for $30 \mathrm{~min}$ and washed three times with sterile PBS. Cuboids $\left(10 \times 10 \times 5 \mathrm{~mm}^{3}\right)$ of tissue were cut with a scalpel and frozen at $-20^{\circ} \mathrm{C}$ until use. The treated mammary-gland tissue was transferred to a 24-well cell culture plate, and $1.8 \mathrm{~mL}$ of TSB medium was added together with $200 \mu \mathrm{L}$ of $1 \times 10^{6} \mathrm{CFU} / \mathrm{mL}$ SA 25-4. The samples were incubated at $37^{\circ} \mathrm{C}$ for $48 \mathrm{~h}$. To remove the nonadherent cells, the wells were washed five times with sterile PBS. SDQ, at a final titer of $10^{7}$ $\mathrm{PFU} / \mathrm{mL}$, was added for 24,48 , or $72 \mathrm{~h}$, and a phage-free treatment was used as the control group. PBS $(10 \mathrm{~mL})$ was then added and the samples shaken vigorously. The change in bacterial titer was determined with the viablecell plate counting method and the change in phage titer was measured with the double-layer agar plate method. All the experiments were performed in triplicate.

\section{Effects of added detergents and environmental factors on $S D Q$ eradication of $S$. aureus}

To determine the infectivity of SDQ in the presence of detergents, the plaque-forming ability of the phage was assessed in various types of detergent. Briefly, SDQ was standardized to a titer of $10^{8} \mathrm{PFU} / \mathrm{mL}$. Molten soft agar ( $5 \mathrm{~mL}, 0.75 \%$ ) was mixed with $100 \mu \mathrm{L}$ of SDQ and $100 \mu \mathrm{L}$ of bacterial culture, and overlain on the surface of solidified basal LB agar. An SDQ suspension $\left(10^{8} \mathrm{PFU} / \mathrm{mL}\right)$ was tested against $S$. aureus in the presence of detergents (SDS, CTAB, Tween 20, Triton X-100, CHAPS, or Brij 35 ) at concentrations of $1 \%$, or with tap water, $10 \mathrm{mM}$ EDTA, or $10 \%$ fetal bovine serum. The plaques were counted after incubation for $6-8 \mathrm{~h}$ at $37^{\circ} \mathrm{C}$. Each test was repeated three times. Established biofilms were also treated with SDQ, detergent, or a combination of phage $(\mathrm{MOI}=10)+$ detergent. Biofilm formation was assessed at $0,4,8,12$, and $24 \mathrm{~h}$. All the experiments were performed in triplicate.

\section{Statistical analysis}

All data are presented as the means \pm standard deviation (SD) of three or more independent experiments $(n \geq 3)$. One-way ANOVA followed by a $t$ test (GraphPad Software Inc., San Diego, CA, USA) was used to evaluate differences between bacterial titers and between phage titers. Differences with $P<0.05$ or $P<0.01$ were considered significant $\left({ }^{*}\right)$ or highly significant $(* *)$, respectively.

\section{Supplementary Information}

The online version contains supplementary material available at https://doi. org/10.1186/s12866-021-02117-1.

Additional file 1: Table S1. Storage stability of SDQ under refrigerated temperature

Additional file 2: Table S2. List of S. aureus. Strains used in this study.

Additional file 3: Table S3. SDQ inhibited biofilm formation.

Additional file 4. Authors' original data for Fig. 2

Additional file 5. Authors' original data for Fig. 3.

Additional file 6. Authors' original data for Fig. 4.

Additional file 7. Authors' original data for Fig. 5. 
Additional file 8. Authors' original data for Fig. 7.

Additional file 9. Authors' original data for Fig. 8.

Additional file 10. Authors' original data for Fig. 9.

Additional file 11. Authors' original data for Fig. 10.

\section{Abbreviations}

ATCC: American Type Culture Collection; CMCC: National Center for Medical Culture Collections; MRSA: methicillin-resistant Staphylococcus aureus: LB: Luria Bertani; TEM: Transmission electron microscopy; MOI: Multiplicity of infection; PFU: Plaque forming units; CFU: Colony-forming units: PBS: Phosphate buffer saline; SEM: Scanning electron microscopy

\section{Acknowledgements}

Not applicable.

\section{Authors' contributions}

WR, SDB and ZJS designed the study, RHR, CH and JYQ performed the experimental work. SJ and RHR performed data analysis, SJ and RHR drafted the manuscript. All authors were involved in revising the manuscript. The author(s) read and approved the final manuscript.

\section{Funding}

This study was supported by the National Natural Science Foundation of China (project no. 31802226), Natural Science Foundation of Heilongjiang Province of China (QC2017021), Heilongjiang Postdoctoral Science Foundation Grant (LBHZ17185), Key research projects on Heilongjiang Farms \& Land Reclamation Administration (HKKY190307), Heilongjiang Bayi Agricultural University Support Program for San Heng San Zong (TDJH201903).

\section{Availability of data and materials}

The datasets used and/or analysed during the current study are available from the corresponding author on reasonable request.

\section{Ethics approval and consent to participate}

The animal experiment was approved by the Institutional Animal Care and Use Committee (IACUC) of Heilongjiang Bayi Agricultural University, Daging China. The animal experiment conventional animal welfare regulations and standards were taken into account.

\section{Consent for publication}

Not applicable.

\section{Competing interests}

The authors declare that they have no competing interests.

\section{Received: 17 September 2020 Accepted: 4 February 2021}

\section{Published online: 20 February 2021}

\section{References}

1. Bradley A. Bovine mastitis: an evolving disease. Vet J. 2002;164(2):116-28.

2. Krömker $V$, Leimbach $S$. Mastitis treatment-reduction in antibiotic usage in dairy cows. Reprod Domest Anim. 2017;52(Suppl 3):21-9.

3. Fox LK. Prevalence, incidence and risk factors of heifer mastitis. Vet Microbiol. 2009:134(1-2):82-8.

4. Jasper DE. Bovine mycoplasmal mastitis. Adv Vet Sci Comp Med. 1981;25: $121-57$.

5. Shahzad W, Altaf M, Ahmad M, Munir R, Amin MT, Khan MS, Sagar MS, Khan MA, Avais M, Akbar GJBB. Prevalence and molecular diagnosis of staphylococcus aureus subclinical mastitis in lactating Nili-Ravi buffaloes (Bubalus bubalis) at livestock Experiment Station, Bahadurnagar, Okara, Pakistan. Buffalo Bulletin. 2013;32(6):1041-5.

6. Gomes F, Saavedra MJ, Henriques M. Bovine mastitis disease/pathogenicity: evidence of the potential role of microbial biofilms. Pathogens Dis. 2016; 74(3):ftw006.

7. Costerton JW, Stewart PS, Greenberg EP. Bacterial biofilms: a common cause of persistent infections. Science. 1999;284(5418):1318-22.

8. Del Pozo JL. Biofilm-related disease. Expert Rev Anti-Infect Ther. 2018;16(1): $51-65$.
9. van Soest FJS, Santman-Berends I, Lam T, Hogeveen H. Failure and preventive costs of mastitis on Dutch dairy farms. J Dairy Sci. 2016;99(10): 8365-74.

10. Dwyer RM. Environmental disinfection to control equine infectious diseases. Vet Clin North Am Equine Pract. 2004;20(3):531-42.

11. Laport MS, Marinho PR, Santos OC, de Almeida P, Romanos MT, Muricy G, Brito MA, Giambiagi-deMarval M. Antimicrobial activity of marine sponges against coagulase-negative staphylococci isolated from bovine mastitis. Vet Microbiol. 2012;155(2-4):362-8.

12. Randall L, Cooles S, Coldham N, Penuela E, Mott A, Woodward MJ, Piddock L, Webber M. Commonly used farm disinfectants can select for mutant Salmonella enterica serovar Typhimurium with decreased susceptibility to biocides and antibiotics without compromising virulence. J Antimicrob Chemother. 2007:60(6):1273-80.

13. Kim M, Weigand MR, Oh S, Hatt JK, Krishnan R, Tezel U, Pavlostathis SG, Konstantinidis KT. Widely used Benzalkonium chloride disinfectants can promote antibiotic resistance. Appl Environ Microbiol. 2018;84(17):e01201-18.

14. Sillankorva SM, Oliveira H, Azeredo J. Bacteriophages and their role in food safety. Int J Microbiol. 2012;2012:863945.

15. Kaistha SD, Umrao PD. Bacteriophage for mitigation of multiple drug resistant biofilm forming pathogens. Recent Pat Biotechnol. 2016;10(2):184-94.

16. Schuch R, Khan BK, Raz A, Rotolo JA, Wittekind M. Bacteriophage Lysin CF301, a potent Antistaphylococcal biofilm agent. Antimicrob Agents Chemother. 2017;61(7):e02666-16.

17. Wroe JA, Johnson CT, García AJ. Bacteriophage delivering hydrogels reduce biofilm formation in vitro and infection in vivo. J Biomed Mater Res A. 2020; 108(1):39-49.

18. Milho C, Andrade M, Vilas Boas D, Alves D, Sillankorva S. Antimicrobial assessment of phage therapy using a porcine model of biofilm infection. Int J Pharm. 2019:557:112-23.

19. Wilson J, Margolin AB. Efficacy of glutaraldehyde disinfectant against Cryptosporidium parvum in the presence of various organic soils. J AOAC Int. 2003;86(1):96-100

20. Jończyk-Matysiak E, Łodej N, Kula D, Owczarek B, Orwat F, Międzybrodzki R, Neuberg J, Bagińska N, Weber-Dąbrowska B, Górski A. Factors determining phage stability/activity: challenges in practical phage application. Expert Rev Anti-Infect Ther. 2019;17(8):583-606.

21. Arciola CR, Campoccia D, Montanaro L. Implant infections: adhesion, biofilm formation and immune evasion. Nat Rev Microbiol. 2018;16(7):397-409.

22. Vergara A, Normanno G, Di Ciccio P, Pedonese F, Nuvoloni R, Parisi A, Santagada G, Colagiorgi A, Zanardi E, Ghidini S, et al. Biofilm formation and its relationship with the molecular characteristics of food-related methicillinresistant Staphylococcus aureus (MRSA). J Food Sci. 2017;82(10):2364-70.

23. Di Pippo F, Di Gregorio L, Congestri R, Tandoi V, Rossetti S. Biofilm growth and control in cooling water industrial systems. FEMS Microbiol Ecol. 2018; 94(5):044.

24. Lister JL, Horswill AR. Staphylococcus aureus biofilms: recent developments in biofilm dispersal. Front Cell Infect Microbiol. 2014;4:178.

25. Morris J, Kelly N, Elliott L, Grant A, Wilkinson M, Hazratwala K, McEwen P. Evaluation of bacteriophage anti-biofilm activity for potential control of orthopedic implant-related infections caused by Staphylococcus aureus. Surg Infect. 2019;20(1):16-24.

26. Lehman SM, Mearns G, Rankin D, Cole RA, Smrekar F, Branston SD, Morales S. Design and preclinical development of a phage product for the treatment of antibiotic-resistant Staphylococcus aureus infections. Viruses. 2019;11(1):88

27. Alves DR, Gaudion A, Bean JE, Perez Esteban P, Arnot TC, Harper DR, Kot W, Hansen LH, Enright MC, Jenkins AT. Combined use of bacteriophage $K$ and a novel bacteriophage to reduce Staphylococcus aureus biofilm formation. Appl Environ Microbiol. 2014;80(21):6694-703.

28. Breyne K, Honaker RW, Hobbs Z, Richter M, Żaczek M, Spangler T, Steenbrugge J, Lu R, Kinkhabwala A, Marchon B, et al. Efficacy and safety of a bovine-associated Staphylococcus aureus phage cocktail in a murine model of mastitis. Front Microbiol. 2017:8:2348.

29. Geng H, Zou W, Zhang M, Xu L, Liu F, Li X, Wang L, Xu Y. Evaluation of phage therapy in the treatment of Staphylococcus aureus-induced mastitis in mice. Front Microbiol. 2020;65(2):339-51.

30. Mi L, Liu Y, Wang C, He T, Gao S, Xing S, Huang Y, Fan H, Zhang X, Yu W, et al. Identification of a lytic Pseudomonas aeruginosa phage depolymerase and its anti-biofilm effect and bactericidal contribution to serum. Virus Genes. 2019;55(3):394-405. 
31. Cai R, Wang Z, Wang G, Zhang H, Cheng M, Guo Z, Ji Y, Xi H, Wang X, Xue $Y$, et al. Biological properties and genomics analysis of vB_KpnS_GH-K3, a Klebsiella phage with a putative depolymerase-like protein. Virus Genes. 2019:55(5):696-706.

32. Gosling RJ, Mawhinney I, Vaughan K, Davies RH, Smith RP. Efficacy of disinfectants and detergents intended for a pig farm environment where Salmonella is present. Vet Microbiol. 2017;204:46-53.

33. Canioni P, Julien R, Rathelot J, Sarda L. Interaction of porcine pancreatic colipase with a nonionic detergent, triton X-100: spectrophotometric studies. Lipids. 1980;15(1):6-9.

34. Møller JV, le Maire M. Detergent binding as a measure of hydrophobic surface area of integral membrane proteins. J Biol Chem. 1993;268(25): 18659-72.

35. Champeil P, de Foresta B, Picard M, Gauron C, Georgin D, le Maire M, Møller $J$, Lenoir G, Montigny C. Interaction of detergents with biological membranes: comparison of fluorescence assays with filtration protocols and implications for the rates of detergent association, dissociation and flip-flop. PLoS One. 2019;14(10):e0222932.

36. Gotoh K, Horibe K, Mei Y, Tsujisaka T. Effects of water hardness on textile detergency performance in aqueous cleaning systems. J Oleo Sci. 2016; 65(2):123-33.

37. Jamalludeen N, Johnson RP, Friendship R, Kropinski AM, Lingohr EJ, Gyles $\mathrm{CL}$. Isolation and characterization of nine bacteriophages that lyse 0149 enterotoxigenic Escherichia coli. Vet Microbiol. 2007;124(1-2):47-57.

38. Abedon ST. Phage therapy dosing: the problem(s) with multiplicity of infection (MOI). Bacteriophage. 2016;6(3):e1220348.

39. Gu J, Xu W, Lei L, Huang J, Feng X, Sun C, Du C, Zuo J, Li Y, Du T, et al. LysGH15, a novel bacteriophage lysin, protects a murine bacteremia model efficiently against lethal methicillin-resistant Staphylococcus aureus infection. J Clin Microbiol. 2011;49(1):111-7.

40. Peng C, Hanawa T, Azam AH, LeBlanc C, Ung P, Matsuda T, Onishi H, Miyanaga K, Tanji Y. Silviavirus phage $\$$ MR003 displays a broad host range against methicillin-resistant Staphylococcus aureus of human origin. Appl Microbiol Biotechnol. 2019;103(18):7751-65.

41. Mazzocco A, Waddell TE, Lingohr E, Johnson RP. Enumeration of bacteriophages using the small drop plaque assay system. Methods Mol Biol. 2009:501:81-5.

42. Xu Z, Liang Y, Lin S, Chen D, Li B, Li L, Deng Y. Crystal violet and XTT assays on Staphylococcus aureus biofilm quantification. Curr Microbiol. 2016;73(4): 474-82.

43. Yang $\mathrm{Q}$, Phillips PL, Sampson EM, Progulske-Fox A, Jin S, Antonelli P, Schultz GS. Development of a novel ex vivo porcine skin explant model for the assessment of mature bacterial biofilms. Wound Repair Regen. 2013;21(5): 704-14.

\section{Publisher's Note}

Springer Nature remains neutral with regard to jurisdictional claims in published maps and institutional affiliations.

Ready to submit your research? Choose BMC and benefit from:

- fast, convenient online submission

- thorough peer review by experienced researchers in your field

- rapid publication on acceptance

- support for research data, including large and complex data types

- gold Open Access which fosters wider collaboration and increased citations

- maximum visibility for your research: over $100 \mathrm{M}$ website views per year

At BMC, research is always in progress.

Learn more biomedcentral.com/submissions 